\title{
Medical History Ongoing
}

National Cancer Institute

\section{Source}

National Cancer Institute. Medical History Ongoing. NCI Thesaurus. Code C83068.

An indication or description that an event or occurrence in an individual's medical history is continuing. 